\title{
Freshening of salinized groundwater in Gdańsk Quaternary aquifer
}

\author{
Maria Przewłócka ${ }^{1}$, Beata Jaworska-Szulc ${ }^{1}$, Bohdan Kozerski ${ }^{2}$, Małgorzata Pruszkowska- \\ Caceres $^{1}$, Adam Szymkiewicz ${ }^{1}$, Andrzej Kwaterkiewicz ${ }^{3}$ \\ ${ }^{1}$ Gdańsk University of Technology, Faculty of Civil and Environmental Engineering, \\ Gdańsk, Poland \\ 2 emeritus, formerly at the Gdańsk University of Technology, Gdańsk, Poland \\ ${ }^{3}$ emeritus, formerly at Polgeol company, Gdańsk, Poland
}

\begin{abstract}
The main Quaternary aquifer in the Gdańsk region connects directly with salt waters of the Martwa Wisła River and the Gulf of Gdańsk. This aquifer has been used for many years by large municipal and industrial intakes located on the marine lowlands, with maximum output $6236 \mathrm{~m}^{3} / \mathrm{h}$ in 1985 . Owing to an intensive exploitation, groundwater in the area of the Old Gdańsk has been salinized by intrusion of salt water from the Martwa Wisła River. Concentration of chlorides in some wells reached $2000-3000 \mathrm{mgCl} / \mathrm{dm}^{3}$, leading to degradation of groundwater resources in this area. As a consequence the "Grodza Kamienna" groundwater intake had to be put out of operation. Salt water intrusion from the Gulf of Gdańsk was provoked in 1970s and 1980s by overexploitation of groundwater resources by three municipal intakes situated on the marine terrace. Concentration of chlorides in some piezometers of the "Czarny Dwór" groundwater intake amounted to $700-$ $1000 \mathrm{mgCl} / \mathrm{dm}^{3}$, however in the pumping wells of the intake it never exceeded the drinking water standards. In 1990s groundwater pumping rates in both areas were lowered. As a result, the chloride concentration decreased and the resources started to recover. Current observations prove that groundwater of the main Quaternary aquifer is freshening and salt water intrusion has stopped. However, elevated concentrations of chlorides are observed in the shallow aquifer, due to anthropopressure.
\end{abstract}

\section{INTRODUCTION}

Costal lowlands around the city of Gdańsk - (the marine terrace and the north-western part of the Vistula River Delta) together with the Gulf of Gdańsk constitute the discharge zone for the regional aquifer system called the Gdańsk Aquifer System (GAS). The recharge area of GAS in on the moraine plateau of Kashubian Lake District. The extent of the system is determined by the confined Upper Cretaceous aquifer which forms the major regional water bearing stratum (Sadurski 1989). Groundwater in the Cretaceous formation occurs mainly in fine-grained glauconitic sands, at the depth about 150 meters below sea level. On the coastal plains and in the western part of the Vistula River Delta the original piezometric level of the Cretaceous aquifer reached 15-18 m a.s.l. The overlying Paleogene- Neogene aquifer consists of Oligocene glauconitic sands and Miocene sands separated by layers of silts and clays with brown coal. The natural piezometric level in this aquifer was about 5-12 $\mathrm{m}$ a.s.1. on the costal lowlands.

However, it is the Quarternary aquifer which has the greatest importance for the water supply in Gdańsk. It spreads on the marine terrace, in the Vistula Delta and also offshore in the Gulf of Gdańsk. The major water bearing series of this aquifer consist of Pleistocene and Holocene fluvioglacial sands and gravels. In the north-eastern part of the Delta fine grained 
sands of marine origin (Eemian interglacial) have replaced fluvioglacial sediments. The thickness of the Quaternary sediments reaches up to $60 \mathrm{~m}$ on the coastal terrace and up to $100 \mathrm{~m}$ in the Vistula Delta. In almost the whole area of the Vistula Delta and partly on the marine terrace the main aquifer is covered with mud sediments of the thickness varying from a few to $30 \mathrm{~m}$. The natural potentiometric surface sloped from the moraine hills to the sea and was about $2 \mathrm{~m}$ a.s.1. along the coastline of the marine terrace (Fig. 1), which indicates that the discharge took place a few kilometers from the shoreline in the Gulf of Gdańsk.

Groundwater of the Quaternary aquifer has been exploited for more than a hundred years. The problem with salt water intrusion appeared in the 1960s, due to significant increase of water abstraction by municipal and industrial wells located in close vicinity of the Martwa Wisła (one of the branches of Vistula) and port channels. Concentration of chlorides in this area reached $2000-3000 \mathrm{mgCl} / \mathrm{dm}^{3}$ with total output from Quaternary aquifer on the marine lowlands amounting to $6236 \mathrm{~m}^{3} / \mathrm{h}$ in 1985 . Five main municipal intakes located here (Fig. 1) - "Lipce", "Grodza Kamienna", "Zaspa", "Czarny Dwór" and "Bitwy pod Płowcami" abstracted $4700 \mathrm{~m}^{3} / \mathrm{h}$.

The influence of intensive exploitation on groundwater salinity became a subject of thorough research and observations after 1970, including development of a monitoring system. The results were presented in numerous reports and publications (Kozerski \& Kwaterkiewicz 1984, 1990, 1997; Kozerski et al. 1992). By the end of 20th century groundwater abstraction has been significantly lowered, which resulted in reducing or even stopping of salt water intrusion.


Figure 1. Hydraulic head distribution for the Quaternary aquifer with the reach of groundwater salinization zone at different periods.

\section{EVOLUTION OF GROUNDWATER SALINITY}

The history of groundwater exploitation is similar in both areas - on the marine terrace and in the western part of the Vistula River Delta. Up to 1960 the total output of two main groundwater intakes - "Grodza Kamienna" and "Zaspa" was quite low and didn't exceed $1000 \mathrm{~m}^{3} / \mathrm{h}$. In the next period, together with building new municipal groundwater intakes "Lipce", "Czarny Dwór", "Bitwy pod Płowcami", the abstraction from the Quaternary 
aquifer rose considerably, reaching $4700 \mathrm{~m}^{3} / \mathrm{h}$ in $1985\left(6236 \mathrm{~m}^{3} / \mathrm{h}\right.$ including industrial intakes).

Because of alarming changes in groundwater quality the exploitation was reduced after 1985. In 1993 pumping at the "Grodza Kamienna" intake had to be stopped due to salinization. After a period of decreasing exploitation lasting till the end of the 20th century, the abstraction stabilized at a more or less constant level 1200 to $1400 \mathrm{~m}^{3} / \mathrm{h}$ for the last 15 years. In 2017 it was $1247 \mathrm{~m}^{3} / \mathrm{h}$ with $476 \mathrm{~m}^{3} / \mathrm{h}$ in the western part of Vistula Delta and 771 $\mathrm{m}^{3} / \mathrm{h}$ on the marine terrace (Fig. 2).



Figure 2. The output of the Gdańsk municipal groundwater intakes from the Quaternary aquifer.

Groundwater salinity changes were tightly connected to the pumping rates, thus three stages of chlorides concentration can be distinguished. The first period of moderate abstraction up to 1960 s can be described as a stage of natural quality. According to Prehn (1931), at the beginning of 20th century, the concentration of chlorides in groundwater of the marine lowlands varied within the range $13.7-19.2 \mathrm{mgCl} / \mathrm{dm}^{3}$. These values are consistent with natural or rather semi-natural hydrogeochemical background determined by Przewłócka (2003) for the period $1954-70$ as $5-40 \mathrm{mg} \mathrm{Cl} / \mathrm{dm}^{3}$ for the marine terrace and 3 $25 \mathrm{mgCl} / \mathrm{dm}^{3}$ for the western part of the delta.

The second stage is characterized by increasing salinization up to maximum concentrations exceeding $2000 \mathrm{mg} \mathrm{Cl} / \mathrm{dm}^{3}$ in 1980. Deep and extended depression cones developed around the main groundwater intakes disturbed natural circulation and provoked salt water intrusion (Fig. 1) - from the bay of Gdańsk and from Martwa Wisła and port channels. The highest concentrations of chlorides occurred in wells of the Grodza Kamienna intake and also in industrial wells situated in this area (concentrations amounting to $2350 \mathrm{mg} \mathrm{Cl} / \mathrm{dm}^{3}$ ). It is important to emphasize that safe yield of Grodza Kamienna intake estimated as $800 \mathrm{~m}^{3} / \mathrm{h}$ was exceeded for a dozen of years contributing to degradation of exploited groundwater 
(Fig. 3). Salinized industrial wells were successively switched off and the saline waters migrated southwards reching wells of the Grodza Kamienna intake. The exploitation of Grodza Kamienna was reduced by the end of 1980s and in 1993 the wells had to be switched off due to high concentrations of chlorides. It is an exceptional case of groundwater degradation of such an abundant municipal intake.

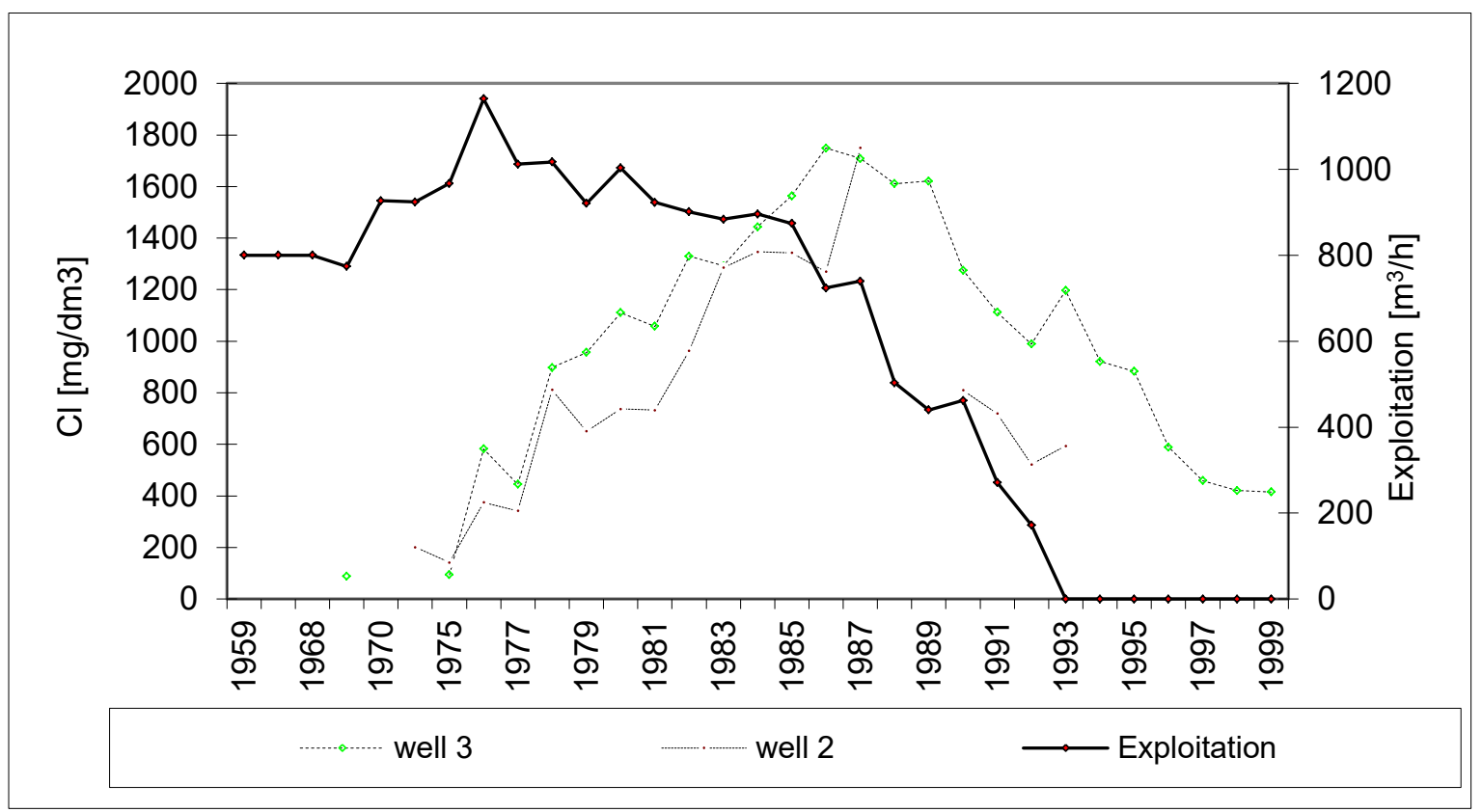

Figure 3. Grodza Kamienna intake; exploitation versus concentration of chlorides in chosen wells.

On the marine terrace salt waters from the Gulf of Gdańsk intruded the exploited aquifer over a limited area indicated in Fig. 1. Zone of saline waters (concentration over $300 \mathrm{mgCl} / \mathrm{dm}^{3}$ ) approached the Czarny Dwór municipal intakes to the distance $300 \mathrm{~m}$ from the line of wells. In piezometers situated $100 \mathrm{~m}$ from the shore line salinization reached maximum value $1000 \mathrm{mgCl} / \mathrm{dm}^{3}$. Water extracted by wells however, demonstrated law chlorides content even over next years, thanks to intensive lateral recharge from the upland. Concentrations rarely exceeded $100 \mathrm{mgCl} / \mathrm{dm}^{3}$ in individual wells. In most wells concentrations amounted $40-60 \mathrm{mgCl} / \mathrm{dm}^{3}$. The state of groundwater quality on the marine terrace at that time was the subject of many publications (Kozerski \& Kwaterkiewicz, 1984, 1990, 1997; Kozerski et al., 1992) and it is presented in Fig.1.

In the third stage concentrations of chlorides dropped (both on marine terrace and in western Delta) thanks to decreased output. The most distinctive desalinization occurred in wells of Grodza Kamienna (Fig.3) where exploitation of groundwater from Quaternary aquifer was stopped for 25 years and groundwater level rose to its natural state. Groundwater monitoring carried out in 8 piezometers (upper and bottom part of the aquifer observed in 4 points) shows concentrations $40-70 \mathrm{mgCl} / \mathrm{dm}^{3}$. Only in one observation well (bottom part of the aquifer) it oscillates around $200 \mathrm{mgCl} / \mathrm{dm}^{3}$ (Fig. 4). 




\section{Figure 4. Concentrations of chlorides in observation wells of the Grodza Kamienna intake, recent monitoring.}

In the area of the Czarny Dwór intake concentration of chlorides in observation wells situated between the sea shore and the line of wells considerably decreased. The lowest amount is observed at the closest distance $(80 \mathrm{~m})$ from the shore line $\left(20-30 \mathrm{mgCl} / \mathrm{dm}^{3}\right)$; in other piezometers and in most of the wells concentrations are in the range $50-80 \mathrm{mgCl} / \mathrm{dm}^{3}$ except for one well which currently has $160 \mathrm{mgCl} / \mathrm{dm}^{3}$ due to anthropogenic contamination (not seawater). Figure 5 presents the decreasing amount of chlorides in piezometers and moderate concentration in a representative well.

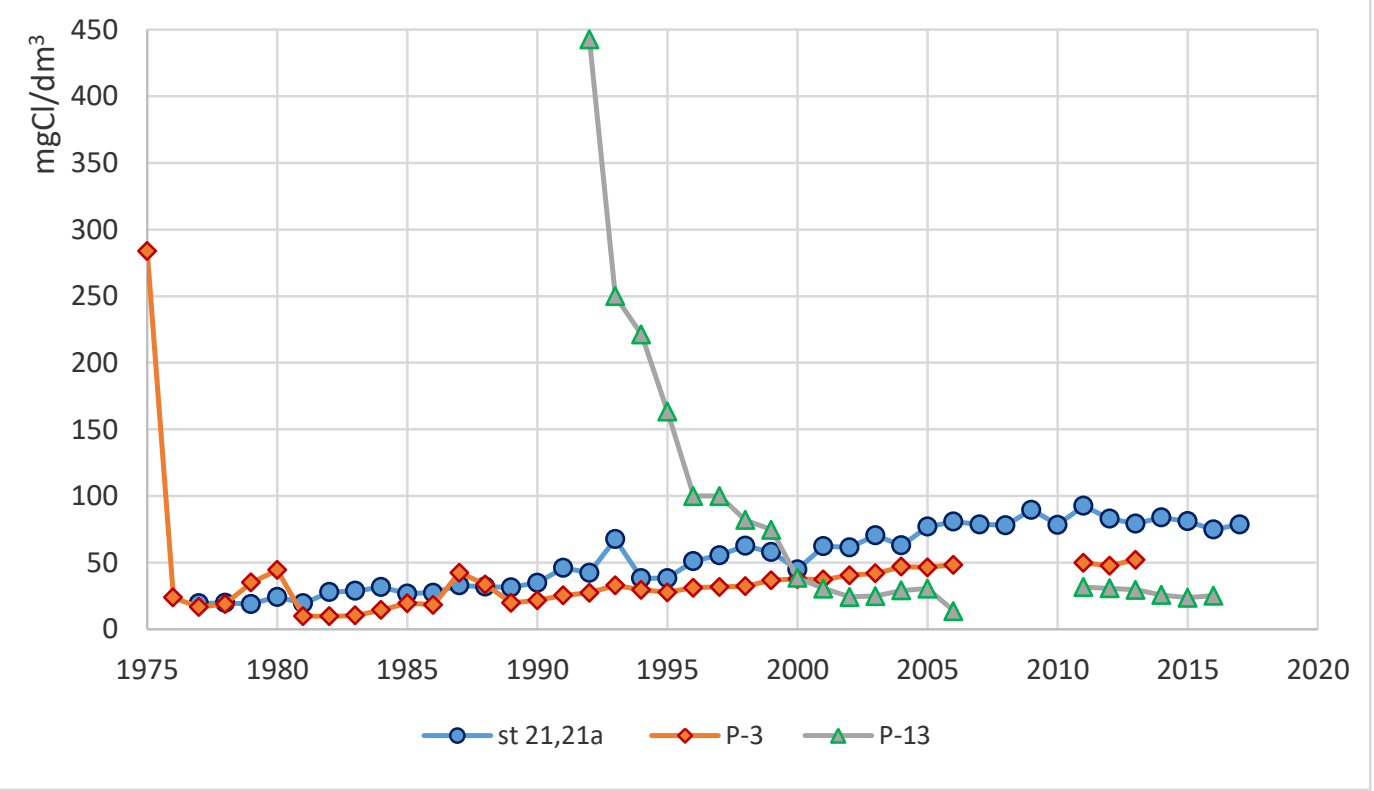

Figure 5. Concentrations of chlorides in a well located $750 \mathrm{~m}$ from the shore line (st 21, 21a) through piezometer P-3 (580 m from the sea) to the piezometer P-13 situated $80 \mathrm{~m}$ from the shore line.

\section{DISCUSSION AND CONCLUSIONS}

Starting from the 1960's groundwater of the Quaternary aquifer was salinized by intrusions from the Gulf of Gdańsk, from Martwa Wisła River and also from port channels due to 
intensive pumping from wells. As a result groundwater resources in the area of the Old Town of Gdańsk were degraded. However, the reduction of well output led to freshening and recovery of the resources. From 1990s decreasing concentrations of chlorides is observed, which can be considered a proof of high and fast renewability of the resources in Gdańsk. At the same time chloride concentrations appear in high and variable amounts especially in the upper part of the aquifer, up to $500-800 \mathrm{mgCl} / \mathrm{dm}^{3}$ in newly drilled observation wells on the opposite side of the line of wells of the Czarny Dwór intake than the sea shore and also in southern part of Gdańsk in western part of the Vistula River delta. It is an effect of developing town with its pollution sources on the surface, especially roads of high traffic and their winter maintenance. Over the last ten years groundwater monitoring system has been considerably developed. New observation wells were drilled in respect to detect possible pollution sources and to protect and monitor groundwater quality.

\section{REFERENCES}

Kordalski Z. et al. 2012. Assessment of the dynamics and quality of groundwater in the area of Gdańsk and Sopot, geoMonitoring - Raport. PGI NRI.

Kozerski B., Kwaterkiewicz A., 1984. Strefowość zasolenia wód podziemnych a ich dynamika na obszarze delty Wisły. Archiwum Hydrotechniki, 31 (3), s. 231-255.

Kozerski B., Kwaterkiewicz A., 1990. The origin and state of Quaternary groundwater salinization in Gdańsk region. Proceedings of the 11th Salt Water Intrusion Meeting, Gdańsk 1990.

Kozerski B., Kwaterkiewicz A., Sadurski A., 1992. Zagrożenia wód podziemnych strefy brzegowej morza w rejonie Gdańska. W Służbie Polskiej Geologii. Wydawnictwa AGH, Kraków, s. 117-131.

Kozerski B., Kwaterkiewicz A., 1997. O zmianach zasolenia wód podziemnych czwartorzędu Gdańska. Współczesne Problemy Hydrogeologii tom VIII, 345-347. WIND-J. Wojewoda, Wrocław.

Lidzbarski M., Kachnic J., Kachnic M., Kozerski B., Kreczko M., Pomianowska H., Prussak E. , Pruszkowska M., 2007. Region dolnej Wisły. Subregion Żuław Wiślanych. W: Hydrogeologia regionalna Polski. T. 1. Wody Słodkie (Red. B. Paczyński, A. Sadurski); 239-246.

Prehn B., 1931. Chemische und geologische Untersuchung von wassern des Freistaates Danzig. Dissertation Genehmigt von der Technischen Hochschule der Freien Stadt Danzig zur Erlangung der Wurde eines Doktor-Ingenieurs.

Przewłócka M. 2003. Zmiany zasolenia na ujęciu „Czarny Dwór” w świetle eksploatacji czwartorzędowego poziomu wodonośnego. Współczesne Problemy Hydrogeologii tom XI, cz. 2. 273-280.

Sadurski A., 1989. Górnokredowy system wód podziemnych Pomorza Wschodniego. Zesz. Nauk. AGH, Kraków.

Szelewicka A,, Kordalski Z., 2013. Hydrodynamics changes in the drainage area of Gdańsk hydrogeological system on the basis of recent research. Biuletyn PIG 456: 595-600, 2013R.

Thiem G., 1916. Expertise on water-supply system development in Gdansk, with two sketches and one plan. Gdansk University of Technology, Gdansk, 15 pp.

Contact Information: M. Przewłócka, Gdańsk University of Technology, Faculty of Civil and Environmental Engineering, 80-233 Gdańsk, Narutowicza 11/12, Email: mprzew@pg.edu.pl 